\title{
PIRJO STÅHLE
}

\section{TQM — lisää laatua opetukseen}

Markkinoille ilmestyy tasaisin välein uusia kehittämisen välineitä. Erilaiset johtamismallit, organisaation kehittämismallit ja työyhteisön

tervehdyttämismenetelmät tarjoavat välineitä työn ja tuotteen jatkuvaan kehittämiseen. Hyvä näin. Välineitä ja herättelyä tarvitaan.

Vaarana on tietysti turtuminen: taas uusi malli, jonka avulla systeemi pannaan urusiksi, taas uutta yrittämistä, joka ei välttämättä johda mihinkään. Väsytään suuntautumaan jatkuvasti uudelleen ja omaksumaan parin vuoden välein uusia totuuksia.

On kuitenkin pakko kehittää ei enää sen vuoksi että käsky käy ylhäältä. Nyt organisaatiot joutuvat kehittämään itseään pysyäkseen hengissä, selvitäkseen yhä kiristyvässä kilpailussa. Yhä pienemmällä budjetilla on tuotettava yhä parempaa laatua ja osattava markkinoida se.
Oppilaitokset ja julkishallinnon organisaatiot tarvitsevat tänään samanlaisia taitoja kuin yritysorganisaatiot ovat tarvinneet jo kauan: kykyä selviytyä kilpailussa, tuottaa mahdollisimman edullisesti mahdollisimman laadukasta, osata mukautua asiakkaiden muuttuviin tarpeisiin ja kyetä markkinoimaan tuotteitaan tehokkaasti.

\section{Total Quality Management}

Total Quality Management (TQM) on laatujohtamisen malli - jopa filosofiaksi kutsuttu joka syntyi Amerikassa jo 30-40 -luvulla. Varsinaisen läpimurtonsa menetelmä teki kuitenkin vasta 50-luvulla, kun TQM:n kehittäjä Walter Deming kutsuttiin Japaniin luennoimaan laadun parantamisesta. Siitä alkoi tiivis yhteistyö japanilaisten kanssa - ja tulokset näkyvät nykyisin hyvin tunnettuina japanilaisina laatutuotteina. Japanin kautta TQM palasi takaisin Yhdysvaltoihin ja Eurooppaan. Yrityssektorilla sitä pidetään edelleen yhtenä tehokkaimmista laadun kehittämisen kokonaismalleista.

1980-luvun loppupuolella TQM alkoi herättää kiinnostusta myös kasvatusalalla. Viime vuosina on julkaistu sekä kirjallisuutta että tehty kokeiluja laatujohtamisen soveltumisesta oppilaitoksiin. TQM:stä liikkuu kuitenkin paljon ristiriitaisia näkemyksiä, ja sen epähumanistiseen traditioon pohjaava ajattelu tuntuu monesta opettajasta vieraalta ja mekaaniselta. Teollisen tuotteen laatu on määriteltävissä ja pilkottavissa selkeiksi standardeiksi, mutta miten se olisi mahdollista kun on kyse ihmisten kasvusta ja kasvatuksesta?

Onkin varmasti epärealistista ajatella, että opetukseen löytyisi täsmällisiä ja kattavia laatustandardeja. Jo TQM:n keskeisten käsitteiden laatu, asiakas, tuote - määritteleminen opetusympäristössä tuottaa vaikeuksia. Miten oppilaitoksen tuote tai asiakas määritellään, on jo osa oppilaitoksen filosofiaa: tietokäsitystä ja ihmiskuvaa. Miten niistä voitaisiin päästä yksimielisyyteen ja kiteyttää ne aina standardeiksi asti?

Mielestäni mennään hakoteille, jos yritetään siirtää teollisuudessa toteutettuja laatujärjestelmiä sellaisenaan opetusalalle. Sen sijaan keskit- 
tymällä TQM:n perusideaan, ydinperiaatteisiin ja -näkemyksiin voidaan arvioida, onko niissä mieltä opetuksen kehittämisen kannalta.

\section{Mitä laadulla tarkoitetaan}

Laatu on aina suhteellista, mutta samalla konkreettista. Se on selkeästi havaittavissa, sanoo Edward Sallis, paljon tuottanut laadun tutkija ja kehittäjä opetusalalla. Sallisin mukaan laatu tekee aina eron tavanomaisen ja erinomaisen välille - siinä suhteessa opetuksen laatua voi verrata esimerkiksi teollisen tuotteen laatuun. Mutta näiden kahden välillä on myös Sallisin mukaan oleellisia eroja.

Ensinnäkin laatua syntyy, kun oppilaitoksen toiminta kehittyy koko ajan sen mukaiseksi, miksi työyhteisön jäsenet sen ovat itse määritelleet.

Toinen tärkeä periaate laadun tuottamisessa on kyky jatkuvaan kehittämiseen. Laadun parantaminen on prosessi, jossa edetään koko ajan - ja itse laatu toteutuu siinä, että yhteisö näkee jatkuvan kehityksen tapahtuvan.

"Itse määritteleminen" on helppo toteamuksena, mutta vaikea toteutuksena. Määritteleminen edellyttää aina laajapohjaista keskustelua henkilökunnan keskuudessa. Miten keskustelu saadaan laajapohjaiseksi, miten keskustelu viritetään, millä foorumilla keskustelu käydään, miten tilanne organisoidaan, miten tulokset kootaan, miten edetään päätöksentekoon, miten jatkokehittelystä sovitaan? Tässä on kautta linjan kyse organisaation yhteisöllisestä kehittämisestä. TQM ei voi toimia pelkkänä instrumenttina, joka voitaisiin tuoda oppilaitokseen ja soveltaa sellaisenaan. Kyse on asteittaisesta prosessista, kulttuurinmuutoksesta, jossa yhteisö vähitellen oppii yhteisöllisen ajattelun ja työn tekemisen tavan.

\section{Laatu oppilaitoksessa}

Laadun määritelmä ei voi tulla oppilaitokseen sen itsensä ulkopuolelta. Laatu ja sen arviointi ankkuroituvat tiiviisti elämän yleiseen arvoperustaan - ja vaatii siten taustalla olevien arvo- jen tekemistä näkyväksi. Laadun kehittämisen perusedellytys on, että yhteisö ja yksilöt sitoutuvat kehittämiseen omakohtaisesti, ulkokohtainen sitoutuminen ei ole riittävää laatutyön onnistumiselle.

Laadun määrittely yhteisesti ei ole kuitenkaan sattumanvaraista. TQM:n mukaan oppilaitos määrittelee itse laatukriteerinsä, mutta se tapahtuu tiettyjen periaatteiden mukaisesti:

- Laatu määräytyy aina asiakkaan tarpeen mukaan.

Oppilaitoksen on siis määriteltävä ensin, kuka on sen asiakas, ketä palvellaan - oppilaita, työnantajia, nykyistä ja tulevaa yhteiskuntaa? Mitä nämä tarvitsevat ja millaisessa muodossa?

- Hyvä laatu on sekä arvioitavissa että koettavissa hyväksi.

Kun opetuksen laatu on hyvä, se myös tuntuu oppilaista siltä.

Olennaisinta laadun mittaamisessa ei ole se, täyttävätkö toiminta ja tulokset täydellisesti annetut kriteerit, vaan olennaisinta on se, näkyykö toiminnassa ja tuloksissa jatkuva kehittyminen. Laatu perustuu siihen, että ollaan jatkuvasti menossa oikeaan suuntaan.

\section{Laadun tuottaminen tapahtuu systeemissä}

TQM:n idea on siinä, että oppilaitos kykenee luomaan systeemin, jossa laadun jatkuva kehittäminen on mahdollista. Laatu ei enää perustu luottamukseen, että jokainen opettaja on ammattitaitoinen ja huolehtii oman ammattitaitonsa pitämisestä ajan tasalla. Laadun perustaksi tulee se, että luodaan systeemi, jossa voidaan yhdessä sopia laatutavoitteista, saada tukea niiden toteuttamiseen, jatkuvaan arviointiin ja siten uusiutumiseen. On kyse prosessista, jossa laatua tuotetaan - ja laatu perustuu siihen miten systeemi pystyy parhaiten ohjaamaan prosessia niin ettei se ole sattumanvarainen.

TQM perustuu kautta linjan systeemiseen ajatteluun. Laatu syntyy aina koko systeemin toi- 
minnan tuloksena, se ei perustu pelkästään yksilöllisiin työsuorituksiin. Kun laatua kehitetään, se tarkoittaa koko systeemin parantamista, huomion kiinnittämistä siihen vuorovaikutus- ja yhteistyöprosessiin, jonka tuloksena tuote syntyy.

Seuraava systeemikuvaukseni perustuu paljolti Frank Bettsin (1992) esittämiin näkemyksiin. Hänen mukaansa kaikki systeemit tarvitsevat energiaa toimiakseen. Jokaisessa systeemissä vaihdetaan jotakin: pankkilaitoksessa rahaa, termodynamiikassa lämpöä, oppilaitoksessa informaatiota. Nämä vaihdon kohteet ovat jo itsessään energiaa (raha, lämpö, informaatio), joka tuottaa systeemiin liikettä. Sillä tavalla systeemi saa tarvitsemansa energian; ilman energiaa se sitä vastoin kuolee. Vaihdon eli vuorovaikutuksen laatu ja määrä kertovat paljon systeemin elinvoimasta.

Systeemi voi olla avoin tai suljettu, mekaaninen tai orgaaninen. Kaikki mekaaniset systeemit ovat suhteellisen yksinkertaisia verrattuna mihin tahansa elolliseen organismiin. Mekaaninen systeemi vaatii toimiakseen vain vähän vuorovaikutusta (vaihtoa) ympäristönsä kanssa. Orgaaniset systeemit sen sijaan ovat monimutkaisia ja vaativat hyvin paljon vuorovaikutusta. Mitä kompleksisempi systeemi, sitä enemmän energiaa se tarvitsee.

Oppiminen tapahtuu aina hyvin monimutkaisissa systeemeissä: ihmisen psyykessä ja sosiaalisessa ympäristössä. Siksi oppilaitos on avoin, orgaaniseen verrattava systeemi, joka tarvitsee jatkuvaan kehittymiseensä paljon energiaa eli runsaasti informaatiota ja sen vaihtoa. Vuorovaikutuksen laatu ja määrä sekä oppilaitoksen sisällä että sen ulkopuolelle on kriittistä kehittämisen onnistumiselle. Mitä elävämpää ja moniulotteisempaa ihmisten välinen vuorovaikutus on ja mitä enemmän se sisältää arvokasta informaatiota, sitä enemmän voimavaroja oppilaitoksella on itsensä kehittämiseen.

Systeemillä on kaksi tapaa säilyä hengissä eli kehittää itselleen tarpeellinen määrä energiaa. Ensinnäkin sillä täytyy olla paljon yhteyksiä omien rajojensa ulkopuolelle eli oman systeeminsä ulkopuoliseen maailmaan. Toiseksi sen täytyy/luoda jatkuvasti uusia energialähteitä omien rajojensa sisäpuolella. Jos kumpikaan näistä ei toimi, systeemi kuolee.

\section{Oppilaitos avoimena systeeminä}

Kun tavoitteena on opetuksen jatkuva kehittäminen, oppilaitoksesta kehittyy samalla systeemi, joka on avoin, orgaaninen, moniarvoinen ja monimutkainen (pluralistinen, kompleksinen). B.H. Banathy (1991) konkretisoi tämän oppilaitokseksi, joka

— tekee yhteistyötä ympäristönsä monien systeemien kanssa

- kykenee muuntumaan joustavasti ympäristön haasteiden mukaisesti

- löytää uusia tavoitteita ja toimintasarkoja ympäristössään

- tekee työtä jatkuvasti muuttuvissa olosuhteissa, jatkuvassa epävarmuudessa ja epäselvyydessä

- toimii luovasti monimutkaisissa ja epäselvissä tilanteissa, jotka ovat sen normaalia arkipäivää

- on oppimiskykyinen organisaatio: kykenee arvioimaan ja kehittämään omaa oppimistapaansa, prosessoimaan nopeasti yhä enemmän informaatiota, jakamaan tietoa laajasti sekä muuntamaan informaation organisaation yhteiseksi tiedoksi

- kehittää jatkuvasti uusia itsearvioinnin tapoja

- ymmärtää että jatkuva tiedollinen uudistuminen vaatii kaksisuuntaista kehitystä systeemissä, erikoistumista ja integrointia.

Banathyn näkemyksen mukaan laatutyötä ei voi tehdä suljetussa systeemissä. Nykyaikainen, kehittyvä oppilaitos tarvitsee runsaasti yhteyksiä itsensä ulkopuolelle: sen tieto-, kontakti- ja yhteistyöverkosto on elintärkeää laadun jatkuvalle kehittämiselle.

\section{Toiminnan tarkoitus}

Toimiva, energinen systeemi tuottaa laadukasta tulosta vain jos toiminnalla on selkeä suunta ja tarkoitus. Pelkän ylläpitämisen aika on ohi. Yhteiskuntamme on siirtymässä deterministi- 
sistä systeemeistä kohti tarkoituksesta käsin ohjautuvia systeemejä - eli diktatorisista kohti osallistuvia systeemejä.

Tämä tarkoittaa käytännössä sitä, että systeemin mieli ja tarkoitus elää sen jokaisessa elementissä: ihmisessä, ryhmässä, yksikössä. Sen jokainen osa tietää paikkansa ja vastuunsa systeemin vaikuttajana, samoin kuin myös toiminnan tavoitteen, tarkoituksen ja merkityksen eli mihin ollaan menossa, miten ja miksi. Systeemin voima on sen jokaisessa osassa, ja sen energia syntyy siitä tavasta jolla osat ovat yhteydessä toisiinsa ja jolla koko systeemi on yhteydessä ympäristön muihin systeemeihin. Mitä kirkkaampi ymmärrys kokonaisuudesta, mitä suurempi yhteenkuuluvuuden tunne ja vastuu toiminnan kehittämisestä systeemin jokaisella jäsenellä on, sitä suurempi mahdollisuus on laadun jatkuvaan parantamiseen.

\section{TQM:n periaatteet opetuksen kehittämisesså}

Yhteenvetona edellisestä voidaan kiteyttää kaksi pääperiaatetta, joiden varassa opetuksen laadun kehittäminen joko onnistuu tai epäonnistuu:

1. Opetuksen laatu syntyy koko systeemin jatkuvasta kehittämisestä.

2. Laadun kehittäminen ja kehittämisen suunta määräytyvät aina asiakkaan tarpeesta.

Asiakkaan tarpeella tässä yhteydessä ei tarkoiteta pelkkiä kohderyhmän mielipiteitä. Asiakas-käsite on ymmärrettävä laajemmin: ketä on tarkoitus palvella, millainen kehitys täyttää parhaiten tulevaisuuden tarpeen, millainen palvelu on mielekästä erilaisissa yhteiskunnallisissa tilanteissa jne. Asiakkaan ja tarpeen määrittely on osa kehittämisprosessia, jossa ulkopuolelta tullut palaute liittyy asiantuntijoiden arvioihin ja omiin kehittämisnäkemyksiin.

Periaatteet ovat yksinkertaiset, mutta niiden soveltaminen käytäntöön vaatii pitkäaikaisen ja työlään, mutta myös innostavan oppimisprosessin. Prosessin tuloksena yhteinen informaatio rikastuu, vuorovaikutus kehittyy ja energia lisääntyy.
Mielestäni oppilaitoksen olennainen laatutyö alkaa silloin, kun keskustelu laadusta, sen tuottamisen periaatteista ja arvioinnista oppilaitoksessa alkaa. Näiden käsitteiden ja periaatteiden käsittely yhdessä alkaa luoda sitä tietoisuutta, jonka varaan toiminta voidaan perustaa. Vuorovaikutuksen peruspilareita - ja siten TQM:n työvälineitä ovat

- kyky käyttää laajapohjaista keskustelua kehittämisen ja päätöksenteon välineenä

- tiimityön organisointi

- systeemin sisällä toimiva palaute- ja arviointijärjestelmä.

Tiimityö on välttämätöntä riittävän laajan keskustelupohjan synnyttämiselle, samoin kuin selkeille toimenpiteille. Tiimit, joilla on vastuuta ja riittävästi toimeenpanovaltaa, ovat kehittämisen perusyksikkö. Tiimit oppivat suurta foorumia nopeammin avoimen ilmaisun, yhteisen informaatiopohjan ja yhteiset laatukriteerit. Kun taito on kehittynyt pienissä ryhmissä, yhteiseen kehittämiseen syntyy asteittain yhä enemmän välineitä.

Palautejärjestelmän kehittäminen on välttämätöntä kehittämiselle. Asiakkaan tarpeet ohjaavat toimintaa (olkoon sitten asiakas oppilas, toiset opettajat, tulevat työnantajat, päättäjät tai tulevaisuuden yhteiskunta). Tieto ja toiminnan perusta ei voi lähteä pelkästään omista kokemuksista, vaan niihin on aina liityttävä riittävästi faktaa asiakkaan näkökulmasta.

\section{Suunnittelun ja spontaanisuuden suhde}

TQM voidaan mieltää hedelmällisenä, oppilaitoksen kehittämistä ohjaavana kehittämisfilosofiana ja toimintaperiaatteina. Mutta se voidaan nähdä myös tiukkana vaihekaaviona tai tuotantoprosessina, joka ikään kuin liukuhihnalta tuottaa tasalaatua yhteiskunnan tarpeisiin. Tällainen koneisto tuottaa ristiriitaisia tuloksia: toisaalta asiat etenevät selkeissä raameissa, hallitusti, toisaalta, mitä tehokkaammin se toimii, sitä vähemmän se sallii spontaaneja reaktioita ja nopeita innovaatioita. Ja siten systeemi kääntyy ajan mittaan itseään vastaan: teho hiipuu, in- 
nostus vähenee, elämä ikään kuin kuolee. TQM:ssä on tällaisen "taylorismin" vaara.

Amitai Etzioni käsittelee organisaatioiden ja yhteiskunnan kehittämistä $\mathrm{mm}$. edellä mainitusta näkökulmasta. Miten spontaanisuuden ja tiukan suunnitelmallisuuden tulisi suhtautua toisiinsa, että saavutettaisiin parhaat tulokset? Liian tiukka suunnittelu tekee systeemistä konemaisen, mikä ei tuota parhaita tuloksia nopeasti muuttuvissa olosuhteissa. Mutta liian vähäinen suunnittelu ja spontaanin prosessin korostaminen tuottaa kyllä alussa intoa, mutta ei pitkän päälle tuota tuloksia: toiminta ikään kuin hajoaa liian moniin intresseihin.

Ikuinen dilemma tuntuu olevan tasapainon saaminen tavoitteisiin ja toimintaan: spontaanisuus ja avoimuus toisaalta, suunnitelmallisuus ja lukkoon lyödyt päämäärät toisaalta. Tasapainoinen rytmi näiden kahden välillä ohjaa parhaiten kehittämisprosessia, antaa sille mahdollisuuden sekä tietoiseen itsensä määrittelyyn että joustavaan reagointiin ympäristön muutoksille.

Mielestäni TQM tuo hedelmällisen näkökulman opetuksen tämänhetkiseen kehittämiseen. Sen on kuitenkin muotouduttava jokaisessa oppilaitoksessa sille sopivaksi avuksi. Teknisenä mallina toteutettuna TQM kääntyy helposti itseään vastaan.

\section{LÄHTEET}

Betts, Frank. How Systems Thinking Applies to Education. Educational Leadership. November 1992.

Etzioni, Amitai 1968. The Active Society. The Free Press. New York.

Banathy, B.H. 1991. Systems Design of Education: A Journey to Create the Future. Englewood Cliffs, N.J.:Educational Technology Publications.

Bradley, Leo.H. 1993. Total Quality Management for Schools. Kogan Page, London.

Deming, W.E. 1988. Out of the Crisis. Cambridge, Mass: Massachusetts Institute of Technology.

Sallis, Edward 1992. Total Quality Management in Education. 